\title{
Does Regional Integration Promote Economic Growth?
}

\author{
Deng Wenbo ${ }^{1,2}$ \\ ${ }^{1}$ Business School, Macau University of Science and Technology, Macau 999078, China \\ ${ }^{2}$ He yuan Polytechnic, He yuan, Guangdong 517000, China \\ "Corresponding author. Email: wenbodeng@163.com
}

\begin{abstract}
Taking the Outline of the Reform and Development Planning of the Pearl River Delta as a natural experiment, this paper collects panel data of 281 cities from 2004 to 2014, and estimates the economic growth level of Guangdong Province, the Pearl River Delta and its surrounding areas by using DID method. The results show that the PRD development planning has not effectively driven guangdong's economic growth; further research shows that the economic growth level of 9 cities in the PRD and 12 cities in the east north and west of Guangdong is lower than the national average level. According to results, this paper puts forward policy suggestions.
\end{abstract}

Keywords: Pearl River Delta, regional integration, economic growth, DID method

\section{INTRODUCTION}

The Pearl River Delta is a leading area of China's reform and opening up, and also an important economic center of China. Therefore, the Pearl River Delta region plays an important role in the reform and opening up of China's economic development. In January 2009, the National Development and Reform Commission of China issued the Outline of the Reform and Development Planning of the Pearl River Delta, or PRD development planning for short, which requires maintaining the steady and rapid economic development of the Pearl River Delta region and accelerating the development of cities in the east north and west of Guangdong.

The academic community has a polarized view on whether regional economic integration can promote economic development. Scholars represented by Liu Shenglong (2011) considered that regional integration promoted regional economic development[1]. Zhang Ting et al. (2013) conducted an empirical analysis of the Pearl River Delta region, believing that regional integration promotes regional economic growth convergence[2]. Some scholars also questioned the effect of regional integration. For example, Hu Zhiding et al. (2010) and Wu Lijun et al. (2015) analyzed the Pan Pearl River Delta economic circle, believing that regional integration did not eliminate the differences in regional economic level, or even expanded the differences to some extent[3-4].

The effect of regional integration on economic growth has been highly valued by scholars. Empirical research has also been conducted on the development of Pearl River Delta integration and on its effect promoting economic growth. However, there is no consensus on whether regional integration can promote regional economic development, and different estimation results can be drawn from the same sample city. Therefore, it is very important to evaluate scientifically whether the PRD development planning can promote Guangdong's economic growth.

From the view of scientific evaluation, some existing research results are insufficient to evaluate the effect of regional integration on economic growth. Firstly, by directly comparing the regional economic performance before and after the implementation of the regional integration policy, we can not identify the influence of other factors before and after the implementation of the policy. Secondly, in order to judge whether there is convergence of regional economic growth by comparing the developed and underdeveloped cities in the region directly, there is a defect that the research object can not meet the requirement of homogeneity. In view of the shortcomings of traditional estimation methods. The academia gradually adopts the difference-in-difference method to estimate the net effect of policy[5-6]. In this paper, the difference-in-difference method is used to estimate the economic growth effect of 9 cities in the Pearl River Delta and 12 cities in the east north and west of Guangdong.

\section{RESEARCH DESIGN}

\subsection{Model Setting Based on Difference-in- Difference Method}

Difference-in-difference method, or DID method for short, is a research tool for scientific evaluation of policy effect, which can effectively separate "policy processing effect". The DID method divides the samples into two groups, one is the experimental group which is impacted by the policy, the other is the control group which is not impacted by the policy all the time. Then, the effect of policy implementation can be judged by examining whether the trend change after policy shock.

This paper uses the DID method to estimate the impact of the PRD development planning on the economic growth of 
paper, the logarithm of per capita GDP is used as the explanatory variable. The interaction coefficient $\beta_{1}$ is the focus of observation. If it is positive, the policy has a positive effect; otherwise, it is a negative effect.

\subsection{Variables Description and Descriptive Statistics}

This paper studies the impact of PRD development planning on Guangdong's economic development, estimates the economic growth level of 9 cities in the Pearl River Delta and 12 cities in the east north and west of Guangdong Province respectively, and takes the logarithm of per capita GDP as the main explanatory variable. Table 1 is detailed variable setting and descriptive statistic.

Table 1 Main variables and descriptive statistics

\begin{tabular}{|c|c|c|c|c|c|}
\hline $\begin{array}{l}\text { variable } \\
\text { name } \\
\end{array}$ & Variable meaning & Calculation method (unit) & $\begin{array}{l}\text { Mean } \\
\text { value }\end{array}$ & variance & $\begin{array}{c}\text { observed } \\
\text { value } \\
\end{array}$ \\
\hline $\operatorname{lnpgdp}$ & $\begin{array}{l}\text { The logarithm of regional } \\
\text { GDP per capita }\end{array}$ & $\begin{array}{c}\text { take the logarithm of regional GDP per } \\
\text { capita (yuan) }\end{array}$ & 10.030 & 0.763 & 3091 \\
\hline $\mathrm{du}$ & Regional variables & $\begin{array}{l}\text { Dummy variable, cities of the experimental } \\
\text { group was } 1, \text { the control group was } 0\end{array}$ & 0.075 & 0.263 & 3091 \\
\hline $\mathrm{dt}$ & Time variables & $\begin{array}{c}\text { dummy variable, years before the policy } \\
\text { was issued, it was } 0 \text {; years after the policy } \\
\text { was issued, it was } 1\end{array}$ & 0.545 & 0.498 & 3091 \\
\hline dudt & Policy variables & $\begin{array}{l}\text { dummy variable, after implementing the } \\
\text { policy, it is } 1 \text {; otherwise, it is } 0\end{array}$ & 0.041 & 0.198 & 3091 \\
\hline gov & Fiscal spending & $\begin{array}{l}\text { regional government fiscal expenditure } \\
\text { /GDP }\end{array}$ & 0.155 & 0.092 & 3091 \\
\hline far & Investment in fixed assets & $\begin{array}{l}\text { (regional fixed assets investment /GDP) } \\
* 100\end{array}$ & 0.619 & 0.245 & 3091 \\
\hline fdi & Foreign investment & $($ regional fdi /GDP)*100 & 0.020 & 0.022 & 3091 \\
\hline save & Household savings & $\begin{array}{l}\text { the total savings of urban and rural residents } \\
\text { /GDP }\end{array}$ & 0.690 & 0.296 & 3091 \\
\hline sindustry & Industrialize & $\begin{array}{l}\text { (output value of regional secondary } \\
\text { industry/regional GDP) } * 100\end{array}$ & 49.540 & 11.120 & 3091 \\
\hline tindustry & $\begin{array}{l}\text { Tertiary industry } \\
\text { development }\end{array}$ & $\begin{array}{l}\text { (output value of regional tertiary } \\
\text { industry/regional GDP) } * 100\end{array}$ & 35.690 & 8.231 & 3091 \\
\hline edu & Education level & $\begin{array}{l}\text { (the number of students enrolled in local } \\
\text { institutions of higher learning/the total } \\
\text { population of the region) } * 100\end{array}$ & 1.471 & 2.090 & 3091 \\
\hline
\end{tabular}

Considering that other economic factors will have an impact on regional economic development, this paper introduces control variables, such as fixed asset investment, foreign investment, financial expenditure, household savings, industrialization, tertiary industry development and education level, based on the practice of Liu Ruiming (2015). This paper uses panel data from 281 cities in 2004-2014 to estimate the impact of the PRD development planning on the economic growth of Guangdong Province.

\section{EMPIRICAL ANALYSIS RESULTS}

\subsection{An Evaluation of the Economic Growth}

In this paper, the samples can be divided into three groups: cities in Guangdong Province, 9 cities in the Pearl River Delta and 12 cities in the east north and west of Guangdong. At the same time, other prefecture level cities 
in China were selected as the control group. Due to the large gaps of economic development level between the cities in the Pearl River Delta and the cities in the east north and west of Guangdong, in order to better ensure the homogeneity between the control group and the experimental group, Select the more developed cities whose per capita GDP is higher than the national average in 2008 as the control group of cities in the Pearl River Delta, and select the less developed cities whose per capita GDP is lower than the national average as the control group of cities in the east west and north of Guangdong. The DID regression estimation is shown in Table 2.

Table 2 Effect of PRD development planning on economic growth

\begin{tabular}{ccccccc}
\hline & \multicolumn{2}{c}{$\begin{array}{c}\text { Cities of Guangdong } \\
\text { Province }\end{array}$} & \multicolumn{2}{c}{$\begin{array}{c}\text { Cities in Pearl River } \\
\text { Delta }\end{array}$} & \multicolumn{2}{c}{$\begin{array}{c}\text { cities in the east north and } \\
\text { west of Guangdong }\end{array}$} \\
\hline lnpgdp & $(1)$ & $(2)$ & $(3)$ & $(4)$ & $(5)$ & $(6)$ \\
\hline dudt & $-0.206^{* * *}$ & $-0.137^{* * *}$ & $-0.273^{* * *}$ & $-0.195^{* * *}$ & $-0.163^{* * *}$ & -0.042 \\
& $(0.033)$ & $(0.035)$ & $(0.038)$ & $(0.040)$ & $(0.026)$ & $(0.036)$ \\
Whether to control & $\mathrm{NO}$ & YES & NO & YES & NO & YES \\
_cons & $9.556^{* * *}$ & $5.350^{* * *}$ & $10.199^{* * *}$ & $3.673^{* * *}$ & $9.180^{* * *}$ & $6.377^{* * *}$ \\
& $(0.039)$ & $(0.289)$ & $(0.042)$ & $(0.895)$ & $(0.029)$ & $(0.277)$ \\
$\mathrm{R}^{2}$ & 0.723 & 0.828 & 0.696 & 0.825 & 0.741 & 0.842 \\
$\mathrm{~N}$ & 3091 & 3091 & 1144 & 1144 & 1947 & 1947 \\
\hline
\end{tabular}

Note: (1) values in brackets are standard errors; (2) values of $* *, * * *$ are significant at the level of $1 \%, 5 \%$, and $10 \%$, respectively; (3) estimation results are calculated by using robust standard errors in stata15.

In Table 2, columns (1), (3) and (5) are the results of not adding control variables, and columns (2), (4) and (6) are the results of adding control variables. It can be found that no matter whether the control variables are added or not, the interaction coefficient $\beta_{1}$ of cities in Guangdong Province is significantly negative, and the interaction coefficient $\beta_{1}$ of cities in the Pearl River Delta is also significantly negative. Similarly, the interaction coefficient $\beta 1$ of the cities in the east north and west of Guangdong is also negative, but not significant if control variables were added. This further shows that the PRD development planning has a negative effect on Guangdong's economic growth, which is mainly caused by the sluggish economic growth of the Pearl River Delta.

\subsection{Robustness Check}

China's three economic zones are the East, the middle and the West. There are certain gaps of economic development level among the three economic zones. Guangdong Province is located in the Eastern Economic Zone with a good economic foundation. Therefore, in order to avoid the possible heterogeneity between cities, this paper takes cities in the Eastern Economic Zone as the control group. Among them, the more developed cities whose per capita GDP is higher than the national average in 2008 are the control group of cities in the Pearl River Delta, and the less developed cities whose per capita GDP is lower than the national average are the control group of cities in the east north and west of Guangdong. The test results of DID estimation are shown in Table 3.

The results of Table 3 show that after adjusting the control group cities, no matter whether the control variables are added or not, the interaction coefficient $\beta_{1}$ of cities in Guangdong Province, cities in the Pearl River Delta and cities in the east north and west of Guangdong are significantly negative at the level of $1 \%$. This shows that the per capita GDP growth of the cities in the Pearl River Delta and cities in the east north and west of Guangdong lags behind that of other cities in the Eastern Economic Zone. The robustness test further supports the above results. 
Table 3 Estimation taking the Eastern Economic Zone city as the control group

\begin{tabular}{ccccccc}
\hline & \multicolumn{2}{c}{$\begin{array}{c}\text { Cities of guangdong } \\
\text { Province }\end{array}$} & \multicolumn{2}{c}{ Cities Pearl River Delta } & \multicolumn{2}{c}{$\begin{array}{c}\text { Cities in the east north } \\
\text { and west of Guangdong }\end{array}$} \\
\hline Lnpgdp & $(1)$ & $(2)$ & $(3)$ & $(4)$ & $(5)$ & $(6)$ \\
\hline dudt & $-0.111^{* * *}$ & $-0.170^{* * *}$ & $-0.193^{* * *}$ & $-0.113^{* * *}$ & $-0.140^{* * *}$ & $-0.198^{* * *}$ \\
& $(0.037)$ & $(0.034)$ & $(0.039)$ & $(0.039)$ & $(0.044)$ & $(0.042)$ \\
Whether to control & NO & YES & NO & YES & NO & YES \\
_cons & $10.005^{* * *}$ & $4.288^{* * *}$ & $10.289^{* * *}$ & $4.329^{* * *}$ & $9.447^{* * *}$ & $5.675^{* * *}$ \\
& $(0.061)$ & $(0.527)$ & $(0.057)$ & $(1.327)$ & $(0.048)$ & $(0.302)$ \\
$\mathrm{R}^{2}$ & 0.708 & 0.864 & 0.703 & 0.868 & 0.735 & 0.871 \\
$\mathrm{~N}$ & 1078 & 1078 & 649 & 649 & 429 & 429 \\
\hline
\end{tabular}

Note: (1) values in brackets are standard errors; (2) values of **,**, are significant at the level of 1\%, 5\%, and $10 \%$, respectively; (3) estimation results are calculated by using robust standard errors in stata 15.

\subsection{An Analysis of the Factors Affecting the Level of Economic Growth}

This paper further estimate the effect various factors driving economic growth to analyze its internal reasons.
Take all other cities in China as the control group to estimate the influence of various control variables of cities in Guangdong Province, so as to determine which factors affect the level of economic growth in Guangdong Province. The DID regression estimation is shown in Table 4.

Table 4 Analysis of factors affecting economic growth level

\begin{tabular}{cccccccc}
\hline & gov & far & fdi & save & sindustry & tindustry & edu \\
\hline dudt & $-0.029^{* * *}$ & $-0.178^{* * *}$ & $-0.018^{* * *}$ & $-0.065^{* * *}$ & $-3.376^{* * *}$ & $3.233^{* * *}$ & 0.191 \\
& $(0.005)$ & $(0.028)$ & $(0.003)$ & $(0.020)$ & $(1.182)$ & $(0.783)$ & $(0.261)$ \\
$\mathrm{R}^{2}$ & 0.313 & 0.451 & 0.066 & 0.005 & 0.120 & 0.029 & 0.189 \\
$\mathrm{~N}$ & 3091 & 3091 & 3091 & 3091 & 3091 & 3091 & 3091 \\
\hline
\end{tabular}

Note: (1) values in brackets are standard errors; (2) values of **,**, * are significant at the level of $1 \%, 5 \%$, and $10 \%$, respectively; (3) estimation results are calculated by using robust standard errors in stata 15.

According to the estimation results in Table 4, only the development level of the tertiary industry is significantly positive, while the government fiscal expenditure level, fixed asset investment, foreign investment, the household savings and industrialization level are significantly negative. The above analysis shows that the factors of economic growth slowdown include the reduction of government fiscal expenditure, household savings, foreign investment and fixed asset investment, and insufficient development potential at the industrialization level. Therefore, the PRD development planning does not effectively promote economic growth.

\section{CONCLUSION AND ENLIGHTENMENT}

Whether regional integration can promote the coordinated growth of economy has always been a topic of concern. Based on the panel data of 281 cities in China, this paper estimates the economic growth level of the cities in the Pearl River Delta and the cities in the east north and west of Guangdong by using the DID method. The results show that the PRD development planning fails to play its policy effect, the cities in the Pearl River Delta and the cities in the east north and west of Guangdong have not promoted rapid economic growth, and still lag behind the cities in the control group to some extent.

Based on the above conclusions, the paper puts forward the following policy recommendations.

Firstly, it is suggested that the government should bring the cities in the east north and west of Guangdong into the development planning of regional integration, so that the cities in the Pearl River Delta and the cities in the east north and west of Guangdong can achieve symbiotic development and jointly promote the rapid economic growth.

Secondly, government departments should play a leading role in economic development and carry out system and mechanism reform. The government should increase financial expenditure on infrastructure and public construction, and appropriately expand the scale of financial transfer payment funds to the underdeveloped areas in the east north and west of Guangdong. 
Thirdly, government departments should formulate favorable financial and tax policies to protect the rights and interests of investors. They should build systems and measures that are conducive to building a good business environment, and ensure that all measures are implemented to mobilize the enthusiasm of domestic and foreign investors, and attract investment as possible.

Fourthly, the government departments should do a good job in the industrial division and layout planning, and make detailed arrangements for the industrial division in the Pearl River Delta and the east north and west of Guangdong, in order to make cities in different regions to achieve dislocation, complementarity and coordinated development as far as possible.

Fifthly, In view of the long-term and important supporting role of industry in economic growth, Guangdong Province should further enhance the competitive advantage of manufacturing industry. Cities in the Pearl River Delta focus on the development of advanced manufacturing industry clusters. Cities in the east north and west of Guangdong can actively cultivate leading industry clusters according to their own advantages to promote long-term and rapid economic development.

\section{ACKNOWLEDGMENT}

This work was supported by Social science project of Heyuan Polytechnic (2019_sk01)

\section{REFERENCES}

[1] Liu Shenglong, $\mathrm{Hu}$ Angang. Transportation Infrastructure and Regional Economic Integration In China [J]. Economic Research Journal, 2011,46 (03): $72-82$

[2] Zhang Ting, Li Hong. A Spatial Analysis of Regional Economic Convergence at City Level in the Pearl River Delta $[\mathrm{J}]$. East China Economic Management, 2013,27 (07): 62-66

[3] Hu Zhiding, Luo Huasong, Li Jiangsu. Development Strategy of Comparative Advantage and Economic Convergence of Pan-Pearl River Delta [J]. Commercial Research, 2010 (5): 26-30

[4] Wu Lijun, Li Fuguan. Study of Economic Growth Differences and Convergence across the Pan-Pearl River Delta Economic Zone [J]. Journal of Guangdong University of Finance \& Economics, 2015,30 (04): 3543

[5] Liu Ruiming, Zhao Renjie. Western Development: Growth Drive or Policy Trap: An Analysis Based on PSM-DID Method [J]. China Industrial Economy, 2015 (06): 32-43
[6] Liu Naiquan, Wu You. Can the Enlargement in Yangtze River Delt Boost Region Economic Common Growth [J]. China Industrial Economy, 2017 (06): 7997 